\title{
EVALUATION OF CUSTOMER SERVICE QUALITY AND SECURITY IN RETAIL NETWORK
}

\author{
doi: $\quad 10.2478 /$ czoto-2019-0082
}

Date of submission of the article to the Editor: $21 / 11 / 2018$

Date of acceptance of the article by the Editor: 14/01/2019

\author{
Damian Pilarz ${ }^{1}$ - orcid id:0000-0002-3961-4232 \\ Sebastian Kot Ko $^{2,3}$ orcid id:0000-0002-8272-6918 \\ ${ }^{1}$ P64 Limited, Poland \\ ${ }^{2}$ North West University, Vaal Triangle, South Africa \\ ${ }^{3}$ Częstochowa University of Technology, Poland, sebastian.kot@wz.pcz.pl
}

\begin{abstract}
One of main purposes of every enterprise is to satisfy the buyer, therefore customer service is perceived as the capability or the ability of satisfying customers expectations and requirements. The present article was devoted to the issue of the quality assessment of customer service assuring the data security on the basis of pharmacies network case study of. The survey was based on prepared questionnaire forms analyzing the quality of the customer service on the basis of three areas. Results of the survey indicate that modern IT tools are very helpful, because they can provide data for analysis of numerous distribution individuals in the context of the quality of customer service in a very fast way.
\end{abstract}

Keywords: quality of customer service quality, quality audit, data security, distribution network

\section{INTRODUCTION}

Undoubtedly, generating revenue is a main purpose of every enterprise. Its achievement is possible by performing certain actions. Depending on the politics, an enterprise is guided by, it can be e.g. price change, cost cutting, change of present suppliers, reduction in the number of employees or also changing trade or market change. Undoubtedly, the most crucial factor having the task to recruit every new client, as well as holding the current one, is nowadays a quality of offered products and services but also customer service quality (Harsono et al., 2017; Ondra et al., 2018; Ulewicz, 2018). So, establishing the correct level of customer service is one of the most important strategic decisions of the enterprise. This level is a crucial factor affecting the income and costs that is profits. Providing customer service on the determined high level is most often connected with the need of performing defined actions, and sometimes even investing into the expansion of the potential but in the end with raising costs.

Quality of customer service is one of the most important processes letting for building enriched relations. It is possible to define the customer service as the operation 
benefitting the customer in a given time and place and embracing activities before and after trade data connected with making exchange. Progressing process of requirements unification as well as the standard of delivered product extorted with the impact of globalisation to markets of individual countries results in a situation in which it is more and more hard to get a considerate competitive edge only by the product or its diversification.

In this context, a purpose of this article in an analysis of the level of customer service in pharmacies network having 11 branches at applying modern IT tools including prepared research methodology.

\section{LITERATURE REVIEW}

Customer service as an essential determinant of getting and supporting customers at is nowadays a universally accepted fact of the commercial activity. Nowadays customer requires more and more high service level. In almost every market segment enterprises started realizing that a higher level of the customer service lets for avoiding price competition. In every market segment the part of customers is guided by a price but there are also such customers for which the level and the quality of service are more important (Christopher, 2005; Civelek et al., 2016; Ngo and Nguyen, 2016).

The quality of service and rather its perception by the customer is main factor deciding that this customer will choose a given contractor. According to assumptions of marketing knowledge, it is possible to state that consumers do not purchase goods or services in the market exchange, but pay for tangible benefits and values chosen from the entire assortment introduced to them. For the contractor the awareness of such verification of selling proposition means the need to implement actions, as a result of which an appropriate offer arises. Marketing activity based on the refinement of the service offer gains more and more great significance, what is connected with the competitiveness increase (Karcz and Ślusarczyk, 2016;Oláh et al., 2018). The quality of products and services is considered as a crucial success factor of the company now and in the future (Styś, 2003; Kljucnikovet al., 2016; Popovic et al., 2018; Akhmetova and Suleimenova, 2018, Kolben, 2014).

Critical features of the perceived service quality are above all (Bielska, 2006):

- Availability - whether the service is readily available in time and space,

- Reliability - whether the reliable firm is a tenderer,

- Knowledge - whether the contractor really understands needs of customers,

- Dependableness - to what extent is reliable and on the repeatable quality level,

- Safety - whether the service is safe, and the risk is low,

- Competences - whether the staff has an adequate knowledge and abilities for the completion of an appropriate service,

- Politeness - whether the staff is sensitize to needs,

- Communication - whether the service was well explained.

A condition of winning the customer loyalty is his satisfaction. It reflects, what people think about the offer of the company, product or service quality and the ratio of the benefit to the price. The customer loyalty is related to how long a given customer holds on to one company.

Directing the offer at appropriate customers is the first step of building the loyalty. For this purpose the management of the organization should realize, who final consumers 
of its products and services are, and next to do everything what they can to get to know their expectations and preferences well. This task is not straight, especially in case of companies, which have extremely fragmented client base or very complex delivery channel. In such situation e.g. personalized company websites, Internet discussion groups, membership cards or loyalty programs offered to customers can become helpful. Using the modern technology enables to get to know a large group of customers (Rutkowski, 2005). An identification of final customers of the company and identifying their needs are only a beginning of building relations with the customer. Streamlining processes occurring in the company is further very important stage. According to opinion of specialists, the change of processes should be conducted from the final customer point of view, not forgetting about the role of partners and cooperators. Every participant in the process should have its bright image, what will enable an efficient and effective reaction for purposes of the customer. While streamlining processes from the point of view of the final customer one should also remember that the company, which wants to be pleased with loyalty of its customers, should take responsibility for all customer's experiences. Delivering a cohesive service by the company and its partners is not possible without providing full image of relations with customer. Everyone, who is in contact with customer, should be able to see the comprehensive image of everything, i.e. transactions and interactions, which took place between customer and company.

The keystone of understanding needs of customers in the scope of service as well as determining the manner, into which these needs can differ in individual market segments looks as follows (Christopher, 2005):

- Defining the field of the competition - often happens that customers compare the modus operandi of a given company not only with other competitors but with suppliers with which they cooperate.

- Analysis of elements of the customer service - only customers can define issues concerning them. This is where an importance of researches providing information about elements of the service perceived by customers, rather than internal definitions formulated in a given company arises. Group interviews, focus groups or in-depth questionnaire forms can constitute the basis for objective determining elements of the customer service.

- Identifying key elements of service - it is extremely important to identify three or four key elements of customer service, which in the main part decide on choice for supplier by customer. Analysis trade - off e.g. can help measure relative meaning, which those customers assign to various aspects of service.

- Market segmentation - it is possible that examinations will show that different customers assign different importance to various components of customer service, namely not everyone guide by the same service priorities. However, even such groups of customers can emerge, which will have similar views on key elements of customer service. On this base new defining of the market on account of preferences of customer service will be possible.

- Comparing activity results with leaders at a given category - using crucial elements of customer service, it is possible to measure results of activity of companies, which were identified by customers as the best at one's class. These comparisons can contribute to ensure higher level of customer service. 


\section{METHODOLOGY AND RESULTS OF ANALYSIS OF THE LEVEL OF CUSTOMER SERVICE IN PHARMACIES NETWORK}

Examining the quality of the level of customer service was conducted cyclically once a month in the period January-April 2018, in 11 branches of pharmacies network in Poland at applying individually drawn up research questionnaire containing 33 standards of evaluation in the division into three areas: 1) Pharmacy appearance external and internal, 2) Exhibition of products, 3) Service standards. Surveys were conducted by representatives of auditing company using the anonymous customer method. While making an evaluation, they assigned following values: 0 - (do not comply with standards);1 - (comply with standards); 3 -not applicable. They entered evaluations to the dedicated web platform, where online results were analysed and were subjected to visualisation in the division into chosen units, collectively, whether in chosen areas. It served as a basis for manager decision in analysed network.

The results for the initial research period for all pharmacies examined in percentage were as follows (Table 1).

Table 1

The degree of customer service standards in the initial research period.

\begin{tabular}{|c|c|c|c|c|}
\hline Pharmacy & The appearance & $\begin{array}{c}\text { Exhibition of } \\
\text { products }\end{array}$ & Service standards & Total evaluation \\
\hline 1 & $64 \%$ & $100 \%$ & $50 \%$ & $65 \%$ \\
\hline 2 & $82 \%$ & $83 \%$ & $71 \%$ & $77 \%$ \\
\hline 3 & $82 \%$ & $100 \%$ & $86 \%$ & $87 \%$ \\
\hline 4 & $82 \%$ & $100 \%$ & $64 \%$ & $77 \%$ \\
\hline 5 & $82 \%$ & $100 \%$ & $71 \%$ & $81 \%$ \\
\hline 6 & $73 \%$ & $100 \%$ & $64 \%$ & $74 \%$ \\
\hline 7 & $82 \%$ & $100 \%$ & $64 \%$ & $77 \%$ \\
\hline 8 & $91 \%$ & $100 \%$ & $71 \%$ & $84 \%$ \\
\hline 9 & $73 \%$ & $100 \%$ & $50 \%$ & $68 \%$ \\
\hline 10 & $73 \%$ & $100 \%$ & $50 \%$ & $68 \%$ \\
\hline 11 & $64 \%$ & $100 \%$ & $50 \%$ & $65 \%$ \\
\hline
\end{tabular}

Taking into account the total evaluation of customer service standards as well as within individual areas, it is possible to indicate the level of achieving the assumed customer service standards and compare it with the sales value. It is also possible to distinguish leading units and entities requiring manager's intervention in order to increase the quality of customer service as a first aim. In detailed analyzes, standards were also distinguished, which were not achieved most often:

- All employees serving customers have white aprons with visible identifiers (name and grade visible)

- The seller offered to buy the products currently within the promotion

- The seller offered to buy a complementary products (probiotics, vitamins, tissues, etc.)

- The seller encouraged the purchase of additional products located in the zone at the cash desk

- The seller packed the purchased products into the bag

Information from reports also provided the basis for decisions regarding the manner and scale of financial motivation of employees. At the end of the research period an 
increase of customer service standards was achieved in all analyzed pharmacies, (except for unit no. 8) as a result of the introduced changes, monitoring the results of corrective actions taken and the continuous adjustment of management activities, (table 2).

Table 2

The change in customer service standards achievement

\begin{tabular}{|c|c|c|c|}
\hline Pharmacy & $\begin{array}{c}\text { Total evaluation on the initial } \\
\text { research period }\end{array}$ & $\begin{array}{c}\text { Total evaluation on the final } \\
\text { research period }\end{array}$ & Change \\
\hline 1 & $65 \%$ & $87 \%$ & $23 \%$ \\
\hline 2 & $77 \%$ & $84 \%$ & $6 \%$ \\
\hline 3 & $87 \%$ & $90 \%$ & $3 \%$ \\
\hline 4 & $77 \%$ & $90 \%$ & $13 \%$ \\
\hline 5 & $81 \%$ & $97 \%$ & $16 \%$ \\
\hline 6 & $74 \%$ & $87 \%$ & $13 \%$ \\
\hline 7 & $77 \%$ & $81 \%$ & $3 \%$ \\
\hline 8 & $84 \%$ & $81 \%$ & $-3 \%$ \\
\hline 9 & $68 \%$ & $81 \%$ & $13 \%$ \\
\hline 10 & $68 \%$ & $90 \%$ & $23 \%$ \\
\hline 11 & $65 \%$ & $71 \%$ & $6 \%$ \\
\hline
\end{tabular}

Selected pharmacies (5 and 3, 4, 10) achieved the highest degree of implementation of customer service standards above $90 \%$. Units 1 and 10 achieved the highest increase in the degree of achieving the assumed customer service standards $(23 \%$ more than in initial study). This information allows not only to determine the level of customer service and motivational policy, but also to assess the effectiveness of the work of managers of individual units. Important problem is data security during collecting and transfer processes. The agents collecting data must use advanced passwords to the platform as well as all the workers analyzing the data as well as the representatives of researched company. Also the people involved in the process should use wi-fi network with careful procedures. Those principle actions allows to avoid reveal sensitive company data.

\section{CONCLUSION}

The quality of customer service evaluation in commercial enterprises seems to be an extremely important element of the management process, probably more important than in manufacturing enterprises. The entire management team should focus on customer information collection related to the level of customer service, but unfortunately this kind of comprehensive research is expensive and not always reliable. Therefore, an alternative method of testing the quality of customer service by trained employees of audit firms is proposed. Of course, it should be noted that the customer service quality evaluation in many cases are not entirely accurate and objective, because due to their immaterial nature they depend on more or less important factors, including the auditor's opinion and its responsibility and reliability. Therefore, the purpose of future research is to determine how to manage the audit of customer service quality in order to achieve the most reliable results. 


\section{REFERENCES}

Akhmetova, S.O., Suleimenova, M.S. Quality management system for improvement of quality and efficiency of food production: Case of dairy products enterprise, Entrepreneurship and Sustainability Issues, 6 (1), 2018, 289-310.

Bielska, I. Współczesny marketing, Studia Emka Publishing, Warsaw 2006

Christopher, M. \& Peck H.: Logistyka marketingowa, PWE, Warsaw 2005

Civelek, M., Ključnikov, A., Dobrovič, J., Hudakova, M., A model of measurement of the quality of business environment in SME segment. Journal of International Studies, 9 (2), 2016, 90-102.

Harsono, S., Widyantoro, H., Prawitowati, T., Rahmat, B. The development of service quality model as a criterion in selecting the banks in Indonesia. Polish Journal of Management Studies, 15 (2), 2017, 82-92.

Karcz, J., Ślusarczyk, B., Improvements in the quality of courier delivery. International Journal for Quality Research, 10 (2), 2016, 355-372.

Kljucnikov, A., Belás, J., Kozubíková, L., \& Paseková, P. The entrepreneurial perception of SME business environment quality in the Czech Republic. Journal of Competitiveness, 8(1), 2016, 66-78.

Koblen, I., Balog, K., Lestyánszka Škůrková, K., 2014. Supply Selection And Supply Chain Maturity - Important Areas of the Quality Production Assurance.Production Engineering Archives, 5/4, 26-30. http://dx.doi.org/10.30657/pea.2014.05.07.

Ngo, V. M., \& Nguyen, H. H. The relationship between service quality, customer satisfaction and customer loyalty: An investigation in Vietnamese retail banking sector. Journal of Competitiveness, 8 (2),2016, 103-116

Oláh, J., Sadaf, R., Máté, D., Popp, J., The influence of the management success factors of logistics service providers on firms' competitiveness, Polish Journal of Management Studies, 17 (1), 2018, 175-193.

Ondra, P., Tuček, D., Rajnoha, R. The empirical quality management practices study of industrial companies in the Czech Republic. Polish Journal of Management Studies, 17 (2), 2018, 180-196.

Popovic, O.B., Nikic, V., Bulatovic, I., Delibasic, M., Modeling perceived quality, customer satisfaction and probability of guest returning to the destination, Montenegrin Journal of Economics, 14 (1), 2018, 69-78.

Rutkowski, K. Logistyka dystrybucji, Warsaw 2005.

Styś A. (ed.), Marketing usług, PWE, Warsaw 2003.

Ulewicz, R., 2018. Outsorcing quality control in the automotive industry. MATEC Web Conf. 183, 03001. https://doi.org/10.1051/matecconf/201818303001 